\title{
OBAMA AND THE MIDDLE EAST, ROUND TWO
}

\author{
Dan Tschirgi ${ }^{1}$ \\ The American University in Cairo
}

\begin{abstract}
:
After years of diplomatic inertia, the seemingly endless Palestinian-Israeli "peace process" was given a new lease on life by the Obama Administration in the summer of 2013. Despite Washington's expressed desire during Obama's first term to "pivot" U.S. foreign policy toward Asia, the revived peace process, along with the Syrian crisis, Iran, and the "Arab Spring" combined to keep Washington focused on its longstanding traditional concerns in the Middle East. Unlike earlier periods, however, American public opinion today may be ready to support a president who seeks to salvage the goal of peace predicated on a two-state solution by directly challenging Israel's policy of promoting increased Jewish settlement construction on occupied Arab lands.
\end{abstract}

Keywords: Obama, Two-state solution, Peace process, Arab Spring, U.S. public opinion, Palestine, Israel, Netanyahu.

\section{Resumen:}

Tras años de inercia diplomática, el aparentemente interminable "proceso de paz" Palestino-Israelí recibió un nuevo empujón por parte de la Administración Obama en el verano del 2013. A pesar del deseo expresado por Washington durante el primer mandato de Obama de girar la política exterior de los EEUU hacia Asia, el proceso de paz reavivado, junto con la crisis Siria, Irán y la "primavera árabe" se han conjurado para que los EEUU mantengan su interés en las tradicionales preocupaciones ligadas al Medio Oriente. En contraste con periodos anteriores empero, la opinión pública estadounidense hoy en día puede estar dispuesta a apoyar a un presidente que persiga lograr el objetivo de un acuerdo de paz basado en una solución en dos estados desafiando directamente la política exterior de Israel de promover la construcción de asentamientos en las tierras árabes ocupadas.

Palabras clave: Obama, solución en dos estados, proceso de paz, primavera árabe, opinión pública de los EEUU, Palestina, Israel, Netanyahu.

Copyright @ UNISCI, 2013.

Las opiniones expresadas en estos artículos son propias de sus autores, y no reflejan necesariamente la opinión de UNISCI. The views expressed in these articles are those of the authors, and do not necessarily reflect the views of UNISCI.

\footnotetext{
${ }^{1}$ Professor of Political Science, The American University in Cairo. Portions of this paper were written while Dr. Tschirgi served as Visiting Professor of Political Science at Istanbul's Kadir Has Universitesi. 


\section{Introduction}

On Tuesday, July 16, 2013, the European Union, following "guidelines" adopted in late June by its Executive Commission, announced that financial assistance to Israeli organizations operating in the occupied territories would be barred as of 2014. The decision blocked a variety of forms of assistance, including grants, loans, and prizes, and was-according to one EU official-explicitly taken to signal the 28-member international organization's "frustration with [Israel's] continued settlement expansion." ${ }^{2}$

Three days later, U.S. Secretary of State John Kerry unexpectedly announced to reporters in the Jordanian capital of Amman that Israel and the Palestinian Authority had agreed to resume negotiations toward a definitive settlement after a years-long hiatus in the peace process. ${ }^{3}$ By Sunday, the $21^{\text {st }}$, rumors, reports, and credible sources in the Middle East were casting serious doubt on Kerry's initial claim. ${ }^{4}$ Former Israeli foreign minister Avigdor Lieberman declared on Facebook that there was "no solution to the Israeli-Palestinian conflict, at least not in the coming years... what's possible and important to do is conflictmanagement." ${ }^{5}$ On the other hand, Hamas, the ruling Palestinian group in Gaza, predictably branded any participation in negotiations a "betrayal." ${ }^{6}$ At the same time, spokesmen associated with the (West Bank) Palestinian Authority insisted that no firm decision had been taken on the question of resuming direct contacts with the Israelis. ${ }^{7}$

In contrast, key members of the dominant Israeli and Palestinian "establishments" supported John Kerry's originally optimistic announcement. Israeli Prime Minister Benjamin Netanyahu told his cabinet that a resumption of the peace process was "a vital strategic interest of the state of Israel." At the same time, Israeli President Shimon Peres praised his Palestinian counterpart's decision to return to the negotiations and encouraged him to ignore the skeptics in the Palestinian camp, saying "you did the right thing." ${ }^{8}$

Last summer's events proved particularly significant for a presidency that has still not clarified the role to be played by the Middle East in the administration's second term, a question of special significance in light of Obama's declared hope of re-focusing foreign policy in order to allot Asia a greater share of official attention.

If a clear and purposeful U.S. foreign policy is to emerge during Obama's second term, major steps must soon be taken to determine whether events in the Middle East will permit even a minimal effort to reorient the established priorities of Washington's approach to foreign policy. The region's fast moving developments-including the UN General Assembly's decision in late November, 2012 to grant Palestine the status of a non-member observer state, and another Gaza Strip crisis that same month, as well as Egypt's counterrevolution in the summer of 2013, and, of course, the events on the diplomatic front of last

\footnotetext{
${ }^{2}$ Croft, Adrian and Fisher-Ilan, Allyn: "EU Bar on Aid to Israelis in West Bank Stokes Israeli Anger", Reuters Online, 16 July 2013,

at www.reuters.com/.../us-israel-settlements-eu-idUSBRE96F0OM2013071...

3 "Kerry Says Israel, Palestinians to Meet to Work Out Final Details for Relaunching Peace Talks", Associated Press, July 19, 2013, at http://www.nydailynews.com/news/politics/kerry-israelis-palestinians-meet-weekwashington-...

${ }^{4}$ Sherwood, Harriet: "Israeli-Palestinian peace talks' resumption put in doubt by both sides," The Guardian, July 21, 2013, at http:// www.guardian.co.uk/world/2013/jul/21/israel-palestinian-peace-talks-doubt.

${ }^{5}$ Ibid.

${ }^{6}$ Ibid.

7 Ibid.

${ }^{8}$ Ibid.
} 
July and August related to Syria, make it doubtful that a second-term Obama Administration will enjoy a respite in which to explore "reorientation" options. ${ }^{9}$

\section{Washington: Reorienting Foreign Policy Priorities?}

The November, 2011 issue of Foreign Policy carried a seminal article by then Secretary of State Hillary Clinton proudly proclaiming "America's Pacific Century." Ms. Clinton noted that the United States had arrived at what she called "a pivot point." ${ }^{10}$ The title's possessive hubris telegraphed the piece's main thrust: given that "the Asia-Pacific has become a key driver of global politics," Mrs. Clinton wrote, "one of the most important tasks of American statecraft over the next decade will...be to lock in a substantially increased investmentdiplomatic, economic, strategic and otherwise-in the Asia-Pacific region." ${ }^{11}$ She devoted much of the article to warning against those who "seek a downsizing of our foreign engagement in favor of our pressing domestic priorities." Although conceding that such views were "understandable," she charged they were "misguided." The truth, she added, was that those "who say that we can no longer afford to engage with the world have it exactly backward-we cannot afford not to."

Reaction to Clinton's article was immediately forthcoming, and has not subsided to this day. Harvard's Joseph S. Nye concluded that Obama was "right to 'pivot' American foreign policy toward East Asia" because the move sent the right message to China while avoiding further friction with Japan. ${ }^{13}$ On the other hand, the editorial staff of the online political publication "This Week," worried that "Obama is probably moving too fast to extend military ties to eager-but-unsavory governments in Myanmar, Laos, Cambodia and Thailand." ${ }^{14}$ In contrast, UCLA political geographer John Agnew employed a critical geography framework to utterly dismiss Hillary Clinton's claim that US foreign policy was "pivoting" to the Asia-Pacific region. ${ }^{15}$ He flatly asserted that the "idea of a pivoting of US foreign policy from the trans-Atlantic to the Asia-Pacific ...makes no sense." 16 Agnew warned against "beguiling metaphors and terms such as "pivoting" that provide the simple language and sound bites that are the stock-in-trade of contemporary politics. Like advertising jingles, they bamboozle even was they seem to clarify."17

There is much to commend Agnew's critique. The inherent implication of the pivoting metaphor - that the US ignored the Asia-Pacific in foreign policy considerations-is patently false. With the exceptions of Iraq and Afghanistan, every major international conflict in which

\footnotetext{
${ }^{9}$ See Clinton, Hillary: "America's Pacific Century", Foreign Policy, November 2011, at http://www.foreignpolicy.com/articles/2011/10/11/americas_pacific century.

${ }^{10}$ Ibid.

${ }^{11}$ Ibid.

${ }^{12}$ Ibid.

13 Joseph S. Nye, "A Pivot That is Long Overdue", New York Times, November 21, 2011, at http://www.nytimes.com/roomfordebate/2011/11/21/does-the-us-need-troops-in-australia/marines-in-australiaits-about-time.

14 "Obama's second term: The case for pivoting to Asia," The Week, November 20, 2012, at http://theweek.com/article/index/236664/obamas-second-term-the-case-for-pivoting-to-asia.

15 Agnew, John: "Is US Security Policy 'Pivoting' from the Atlantic to Asia-Pacific? A Critical Geopolitical Perspective," Dialogue on Globalization, Friedrich Ebert Stiftung, September, 2012, at http://library.fes.de/pdffiles/iez/global/09318.pdf.

${ }^{16}$ Ibid., p. 8 .

${ }^{17}$ Ibid., p. 5.
} 
the US has engaged since the Spanish-American War-including World Wars I and II, the Korean War, and Vietnam-has seen American troops involved in combat in Asia. Moreover, the degree of the US military, economic, political, and cultural investments linked to the region resulted from policies that had been consciously pursued by administrations long antedating Obama's so-called "pivot."

Looked at carefully, the text of Hillary Clinton's 2011 article is a curious combination of misdirection, hyperbole, and factual assertion. Misdirection comes at the article's outset, in the first sentence, in which Clinton claims that the United States "stands at a pivot point." ${ }^{18} \mathrm{~A}$ few pages later, however, she offered the following-hardly contentious-justification for an Asian-Pacific orientation to US foreign policy:

By virtue of our unique geography, the United States is both an Atlantic and a Pacific power. We are proud of our European partnerships and all that they deliver. Our challenge now is to build a web of partnerships and institutions across the Pacific that is as durable and as consistent with American interests and values as the web we have built across the Atlantic. That is the touchstone of our efforts in all these areas. ${ }^{19}$

Jean-Loup Samaan, a Middle East expert in NATO's Defense College, offers a sober and balanced view of Obama's purported "pivot":

Despite all the talks of a US shift to Asia, the efforts of the Obama administration have lately been dedicated to Middle Eastern crises. The diplomatic agenda of the last months is revealing: last November, in her last days of Secretary of State, Hillary Clinton had to postpone a scheduled visit to Asia to go to Israel to seek truce after the Israeli operation "Pillars of Defense" in retaliation to rocket strikes by Palestinian factions in the Gaza Strip. The first key decision of her successor, John Kerry, was not directed at the Pacific theater but was a pledge for US commitment to provide non-lethal aid to the Syrian opposition amounting to $\$ 60$ million. Additionally, Chuck Hagel, freshly nominated as Secretary of Defense after a long controversy in Congress regarding past positions on US-Israel, met ...his first foreign counterpart: Ehud Barak, Defense Minister of Israel. In fact, during his hearing at the Senate, Hagel evoked Israel 136 times in the hearing and Iran 135 times. Conversely, China was barely mentioned. ${ }^{20}$

Mrs. Clinton's article notwithstanding, it appears that the new Obama administration will have no choice but to confront the perilous problems rooted in the Middle East.

\section{The Middle East as a Problem}

For Washington, the problematical nature of today's Middle East stems from two issues: the various events linked to the so-called Arab Spring, and-on the other hand-the perennial problem of Palestine.

The late political sociologist David Apter once wrote that the study of modernization brings one's attention back to "first principles," both analytic and normative. Apter claimed

\footnotetext{
${ }^{18}$ Clinton, op. cit.

19 Ibid.

${ }^{20}$ See Samaan, Jean-Loup: 'US Locked into the Middle East', Al Monitor, 13 March 2013, at http://www.almonitor.com/pulse/originals/2013/03/us-pivot-asia-middle-east-crises-obama-kerry-aid-syria.html.
} 
the challenge of studying "modernization"—or what is now called "development"—mainly lay in determining how we might learn something about the flow of history and its moral significance. ${ }^{21}$ These large issues are essentially philosophical and not amenable to scientific inquiry. It is necessary to recall this point as we look at today's Arab world.

For two solid years, the central feature of Middle East politics has been the so-called "Arab Spring," the generalized series of political upheavals currently wracking the region. The roots of the problem can be traced to the area's recent history. As Ibrahim Elnur writes:... sixty years of postcolonial authoritarianism in the Middle East was instrumental in eroding old forms of political associations and platforms. Under the forms of government that prevailed during those six decades, governmental authority based on political patronage was characterized by expanded access to basic needs, including education and health. But that same authority also served to build up and maintain a form of crony capitalism that was cultivated carefully through selected interaction with an increasingly globalized world. ${ }^{22}$

The process Elnur describes took time, allowing at least two generations to experience its full effects. The slow rate of change permitted immediate circumstances to affect the central economic dynamic Elnur outlines. Thus, depending on local conditions, ethnic, regional, tribal, sectarian, and, ultimately, ideological (secular/religious), fault lines colored the progression that led to the Arab Spring. This insidious process eventually undermined social cohesion.

In addition, the nature of the patronage package changed over the years. Essentially, the initial formula was similar throughout the region, produced by a context that saw citizens accept non-participatory political roles in exchange for tangible benefits. The basic problem was that the resulting authoritarian systems became victims of their own success. Rising expectations among the general populations and the early successes of increased health care and social services eventually fueled a negative dynamic. It was not long before the poorer societies of the region were forced to modify existing patronage systems. Thus, for example, Egypt, with the Arab world's largest population and a relatively weak resource base, found itself forced to drastically limit the regime's commitment to guarantee full employment by the late 1970 s. $^{23}$ At the same time, Egypt's government had to witness a steady decline in the quality of state-sponsored educational and social welfare programs to levels that were often only third-rate mockeries of models copied from abroad. Forty years later, even the oil-rich rentier societies of the Gulf-including Saudi Arabia, Bahrain, and Kuwait-also faced the problem of restructuring their patronage packages. ${ }^{24}$

The problem of education was central to the unproductive course of the Arab world's development. Under the impact of population growth, its role as an avenue to social mobility rapidly collapsed. Coupled with the stark reality of growing unemployment and the existence

\footnotetext{
${ }^{21}$ Apter, David E. (1965): The Politics of Modernization, University of Chicago Press, pp. 5-6.

${ }^{22}$ Elnur, Ibrahim (2013): "The Implosion of Political Patronage Regimes in the Middle East," in Dan Tschirgi, Walid Kazziha, and Sean McMahon, Egypt's Tahrir Revolution, Boulder, CO and London, UK: Lynne Rienner Publishers, p. 131.

${ }^{23}$ Binzel, Christine: "Decline in Social Mobility: Unfulfilled Aspirations among Egypt's Educated Youth", IZA DP No. 6139, November 2011, p. 8, at http://ftp.iza.org/dp6139.pdf.

${ }^{24}$ Forstenlechner, Ingo and Rutledge, Emilie: "Unemployment in the Gulf: Time to Update the "Social Contract", at http://www.mepc.org/journal/middle-east-policy-archives/unemployment-gulf-time-update-social.
} 
of fossilized authoritarian political systems, the region's "youth bulge" set the stage for the Arab Spring's 2011 eruption. ${ }^{25}$

The first events of the Arab Spring were played out in Tunisia and Egypt. Initially, they were produced by the disaffected educated youth of both countries. As time went on, however, the demand for democracy led to the victory of Islamist groups. Tunisa came under the sway of the El Nahda Party in 2011, while in the summer of 2012, Egypt found itself under a parliament in which Islamists-the Muslim Brotherhood and various Salafi parties-held over $65 \%$ of the seats. The spreading popular upheavals soon engulfed Jordan, Bahrain, Yemen, Libya, and Syria. What these events "have unleashed is a complex set of reconfigurations and reinventions that are likely to yield an untidy blend of old and new". ${ }^{26}$ Egypt's counter-revolution was played out in in the summer of 2013, and provided a compelling example of the uncertainties generated by the region's turmoil.

But the ongoing problems of the Arab world are best symbolized by the ferocity of Syria's civil war. The country's authoritatian president, Bashar al-Assad, can only label his opponents "traitors" and "terrorists." On the other hand, the multi-faceted opposition forces, among which Islamist militants are playing an ever-growing role, refuse to consider any solution that does not entail al-Assad's removal from office. The viciousness and inflexibility marking all sides in the conflict is linked to its character as a struggle over the definition of Syrian identity. At the same time, of course, what may have begun as a civil war soon metamorphosed into a far more complex issue as it became internationalized, turning into "a regional proxy war...within the territorial limits of the Syrian state." 27 The primary protagonists in the Syrian conflict have actually become Iran, the Arab Gulf states, and the latter's allies.

The fundamental question of identity lies at the root of the various conflicts that collectively form the Arab Spring. Each of the societies experiencing it has also undergone forms of what might be termed "arrested" or "distorted" development, caused by historical circumstances which constrained their socio-political options.

From the outset, Washington exhibited deliberate caution in its reaction to the Arab Spring. To date, this approach has remained definitive. Notwithstanding the object of policy_whether Tunisia, Egypt, or any other polity — the administration's response has been cautiously formed, and carefully formulated. Above all, it has-at least until very recently-been careful to avoid excessive commitment. ${ }^{28}$

\footnotetext{
${ }^{25}$ See, for example, Stanojević, Nataša: "Social and Economic Implications of Demographic Trends in the Region of the Near East and North Africa", Megatrend Review, vol. 2, no.2 (2005), at http://www.megatrendreview.com/files/articles/003/e06-Stanojevic.pdf; and Mirkin, Barry: "Population Levels, Trends and Policies in the Arab Region: Challenges and Opportunities," United Nations Development Programme, Regional Bureau for Arab States, Arab Human Development Report, Research Paper Series, (2010), at http://www.arab-hdr.org/publications/other/ahdrps/paper01-en.pdf

26 Shokr, Ahmad: 'Reflections on Two Revolutions', MERIP, no. 265 (Winter 2012), at http:// www.merip.org/mer/mer265/reflections-two-revolutions; Although Shokr's descriptive phrase was originally applied only to Egypt, I believe it can be validly applied to the Arab Spring as a whole.

${ }^{27}$ McMahon, Sean: "Syria's Two Years Crisis: 2011-2013", Lecture Delivered at the American University in Cairo to the Model Arab League, September 17, 2013.

28 Tschirgi Dan: "The United States and the Tahrir Revolution," in Tschirgi, Dan; Kazziha, Walid and McMahon, Sean F. (eds.) (2013): Egypt's Tahrir Revolution, Boulder, CO and London, Lynne Rienner Publishers, pp. 233-54.
} 
The most to be hoped for a second Obama administration is that it will manage to replicate this difficult achievement. The hard but unavoidable truth is that the Arab Spring can only be defined as a "Developmental Crisis." Such a phenomenon is unique as an issue affecting an entire region of the world. Moreover, it also presents a singular challenge for all external actors having to formulate policies toward the region. The prolonged and fruitless hand-wringing of all major non-Middle East states in reaction to Syria's plight is the most obvious case in point.

\section{The Palestine Issue}

It is a supreme irony that the second issue confronting the Obama II administration in the Middle East today is of a far simpler order of complexity than the Arab Spring. For decades, the Palestine problem was billed as the world's quintessential political dilemma. The familiar theme of a tragic clash between two equally justifiable positions was raised and re-raised over the decades, particularly after the 1967 War's outcome dealt a virtual death blow to propagandistic imagery of an outgunned Israel bravely defending itself against malevolent Arab aggressors.

In the 1970s, Egypt broke ranks with the Arab world and embarked on the series of diplomatic maneuvers that culminated in its 1979 Peace Treaty with Israel. In due course, this was followed by the Israel-Jordan Peace Treaty of 1994, along with a visible relaxation of the Arab world's rejection of the Jewish State. In 1993, the Oslo Process appeared to have finally penetrated the barrier of implacable hostility that had divided Arabs and Jews in Palestine since the early years of the Twentieth Century. Predicated on the idea of an ultimate two-state solution, Oslo led to Palestinian self-government through the Palestinian National Authority in the occupied territories.

With that, the Palestine issue returned full circle to its original nature as a clash between Zionists and Palestinian Arabs. However, the two decades since the Oslo Process' launching have seen little movement toward a two-state solution. This result has been partly due to the rise of Israel's right wing and the corresponding political eclipse of that country's more liberal tendencies. It was also the result of Palestinian leader Yasser Arafat's stubborn determination to refuse opportunities to compromise prior to his death in $2004 .^{29}$

In 2001, Palestinian and Israeli negotiators at the Egyptian town of Taba came soclose to reaching agreement on the modalities of a two-state solution that Israeli Foreign Minister Shlomo Ben Ami exuberantly told reporters "We can say we have the basis for an agreement, which can be implemented and achieved after the elections in Israel." ${ }^{30}$ Ben Ami spoke too soon. Israel's 2001 elections toppled the Labour government of Ehud Barack and led to the

29 The White House became very active in peacemaking, hosting the Camp David Summit of 2000 and continuing to promote a settlement right to the end of Clinton's term in January, 2001. Clinton's efforts culminated in the Taba Summit of January 21-January 27, 2001, which marked the collapse of the US peacemaking drive (See, Plen, Esther: "Middle East Peace Plans Background," CFR, at http://www.cfr.org/israel/middle-east-peace-plans-background/p7736; See also, Jewish Virtual Library: "The Clinton Parameters," January 7, 2001, "Excerpts of U.S. President Bill Clinton's Remarks to the Israeli Policy Forum on Israeli-Palestinian Violence and His Proposals for a Peace Accord", at http://www.jewishvirtuallibrary.org/jsource/Peace/clintplan.html.

30 "Mideast Negotiators Want to Continue Talks After Israeli Elections", CNN.Com, January 27, 2001, at http://archives.cnn.com/2001 WORLD/Mideast/01/27/Mideast.02/index.html. 
Likud government of Ariel Sharon, a man already on record saying he would not honor any agreement that might be reached between Barack's negotiators and the Palestinians.

The next decade or so saw a string of right-wing Israeli governments, none of which viewed the possibility of a two-state solution with enthusiasm. Ariel Sharon whose government ruled from 2001 to 2006, until a stroke ended his political career, seemed to have had a change of heart in the final months of his active political life, for he founded a new party-Kadima - and apparently hoped to lead it to victory on a platform that would have supported some version of a two-state solution. Ehud Olmert assumed Sharon's responsibilities after the fateful stroke and then became Prime Minister in his own right, presiding over a government from 2006 to 2009. Finally, there was Benjamin Netanyahu, who clung to the original right wing option, the Likud Party, and is again Israel's leader today. Each of these leaders presided over policies that progressively expanded the range of Israeli settlements on occupied Arab territories.

By late 2012, Israel's increasingly aggressive settlement policies had so alienated international opinion that they helped produce the overwhelming U.N. General Assembly vote $(138$ - 9) that raised the Palestine delegation's status to a "non-member state observer." In the days just prior to the November 29, 2012 General Assembly vote, British foreign minister William Hague called "on the United States to show the necessary leadership...because they have crucial leverage with Israel..." He went on to note "we're coming to the final chance maybe for a two-state solution for the Israeli-Palestinian conflict," echoing a point also made earlier to the General Assesmbly by Palestinian leader Mahmoud Abbas. ${ }^{31}$ Hague's own government proceeded to cast one of the forty-one abstentions in the vote over upgrading the Palestinians' status.

Having won his re-election bid-despite Netanyahu's obvious preference for his Republican rival-Barak Obama prepared to make an official visit to Israel early in his second term. He went in the latter part of March, 2013. The full text of the president's speech to a largely young audience in Jerusalem's Convention Center on March 21 was run in the New York Times. It makes for fascinating reading. On one level, it was clearly a paean to Israel and virtually all things Israeli. On others, however, it seemed intricately constructed, multi-layered and often pregnant with unstated meanings. In part, the discourse called on young Israelis to protect Israel's long-term security by supporting the two-state option, in part the speech also appealed to Israelis' sense of fairness, asking them to put themselves in Palestinians' shoes, and in part it also held out the possible economic benefit of future IsraeliPalestinian cooperation. At the same time, the speech could also have been understood as Obama's apology to history for having failed to fight for the two-state solution.

On the whole, though, Obama's address was received as a ringing endorsement of the existing relationship between the United States and Israel. As discussed in the following section, strong grounds exist for questioning Obama's failure to challenge the Netanyahu government directly over its devastating assault on the two-state solution. In the meantime, though, it will be useful to look a bit more closely at Obama's March 21 Jerusalem speech.

\footnotetext{
${ }^{31}$ Aronson, Geoffrey: "The Occupation Returns to Center Stage," Foundation for Middle East Peace, Settlement Report, Vol. 22, no. 6 (November-December, 2012), p. 1., at http://www.fmep.org/reports/archive/vol.-22/no.6/the-occupation-returns-to-center-stage; See: "Full Text of Mahmoud Abbas's Speech to the UN General Assembly, November 29, 2012", The Times of Israel, November 29, 2012, at http://www.timesofisrael.com/fulltext-of-mahmoud-abbass-speech-to-the-un-general-assembly-november-29-2012/.
} 
The art of politics is that of incorporating power-relations into the body of human interactions. At the outset of his speech Obama made light of the well-known frictions that had long marred his personal relations with Benjamin Netanyahu by referring to a popular satirical Israeli television show:

...I-I want to clear something up, just so you know: any drama between me and my friend Bibi over the years was just a plot to create material for Eretz Nedheret. That's the only-only thing that was going on. We just wanted to make sure the writers had good material.

Having reassured the audience that all was well between "Bibi" and himself, Obama moved on to more substantial issues. He was very clear that his administration remained committed to a two-state solution: "Negotiations," he said, "will be necessary, but there's little secret about where they must lead: two states for two peoples-two states for two peoples." 33

Obama suggested no means for persuading Israel to pursue this goal other than the good-hearted idealism of some of those in his youthful audience. On relations between the United States and Israel, Obama offered a dynamic vision, one that left room for change. It might - though with difficulty — be argued that in the following passage Obama left himself some room for flexibility by suggesting that not all change in the relationship would necessarily be positive:

But the source of our friendship extends beyond mere interests....We are governed not simply by men and women but by laws. We're fueled by entrepreneurship and innovation, and we are defined by a democratic discourse that allows each generation to reimagine and renew our union once more. So in Israel we see values we share, even as we recognize what makes us different. ${ }^{34}$

On a different tack, Obama used Ariel Sharon's own words to remind his audience of the view Sharon developed late in his career:

"It is impossible to have a Jewish, democratic state and at the same time to control all of Eretz Israel. If we insist on fulfilling the dream in its entirety, we are liable to lose it all." 35

The president only raised the issue of power twice during his speech, but did so in two consecutive sentences that contrasted Israel's status as "the most powerful country in this region" with America's stature as "the most powerful country in the world." 36 Any reading of the remarks must reveal them for what they were: a pointed reminder of the power differential between Israel and the United States. Moreover-while many who heard the speech would probably say that it indicated "unconditional support" for Israel, the president went out of his way to deny that interpretation. In his own mind, then, he saw himself as expressing sympathy and support, but only limited support:

\footnotetext{
32 "Transcript of Obama's Speech in Israel", New York Times, March 21, 2013, at http://nytimes.com/2013/03/22/world/middleeast/transcript-of-obamas-speech-i...

${ }^{33}$ Ibid.

34 Ibid.

${ }^{35}$ Ibid.

${ }^{36}$ Ibid.
} 
...politically...the easiest thing for me to do would be to put this issue aside, just express unconditional support for whatever Israel decides to do. That would be the easiest political path. ${ }^{37}$

Finally, near the end of his talk, Obama turned to what was earlier suggested might be seen as an "apology", or explanation, to history and to the Palestinian people:

....as a politician, I can promise you this: Political leaders will never take risks if the people do not push them to take some risks.

It takes little imagination to see how Obama's personal situation at the outset of his second term would have allowed-perhaps almost forced-him to relate to these words at a very gut-wrenching level.

So, what did the president's Jerusalem address accomplish? On the one hand it seems to have effectively repaired, at least for a while, the strained relationship between the Obama administration and Israel's current government. It also effectively placed the United Statesonce again - on record as supporting a two-state solution in Palestine and opposing Israel's settlement policies as counterproductive to the cause of peace. It also strongly suggested that the Obama administration would be pleased to see a change in Israel's settlement policies brought on by the activism of Israel's youth. Then too, Obama managed to get on record his explanation, or apology, for not having confronted Netanyahu's obstructionist approach to the two-state goal. Finally, the speech reinforced Washington's commitment to Israel's security, going so far as to have the president pledge in Hebrew, "so long as there is a United States of America, 'Ah-tem lo lah-vahd.' You are not alone." ${ }^{38}$ But it had also indicated quite clearly that Obama did not think he was extending unconditional support to the Jewish State.

From a perspective that views the Israeli public as still deeply traumatized by the Holocaust, the solicitude Obama demonstrated for Israel's security fears makes sense. Under the influence of this paradigm, Israel's insecurity elicits sympathy and understanding. In time, the thinking goes, Israel will normalize and it may then be treated as a state which understands that security can never be absolute. Other perspectives are not so charitable. Many observers see Israel's policies as not springing from the traumatic experiences of past generations, or, at best, as being only partly generated by them. In this view, trauma has in effect long since been supplemented, if not supplanted, by less sympathetic motivations, among which are ideological fanaticism, racism, and simple short-sightedness combined with the arrogance of power. ${ }^{39}$

Americans should be alarmed by the ease with which Washington has committed them to support a government such as Netanyahu's, which seems to care not at all how much

\footnotetext{
37 Ibid.

${ }^{38}$ Ibid.

${ }^{39}$ On "ideological fanaticism," see the 1987 article by Rosemary Ruether, Georgia Harkness Professor of Theology at Garrett-Evangelical Theological Seminary in Evanston., Ohio, "Invisible Palestinians: Ideology and Reality in Israel," which originally appeared as an article in The Christian Century, July 17, 1987 and now can be found online at http://www.religion-online.org/showarticle.asp?title=1026 On racism, see Prusher, Ilene: "Let's Face It: Israel has a Racism Problem," Ha'aretz, April 16, 2013, at http://www.haaretz.com/blogs/jerusalem-vivendi/let-s-face-it-israel-has-a-racism-problem.premium-1.508926; on "short-sightedness", see Kashmeri, Sarwar: "Time Running Out As Israel Cuts the Grass," at http://www.huffingtonpost.com/sarwar-kashmeri/us-israel-policy b 2161000.html; on "arrogance of power", see Noam Chomsky's interview with Al-Mufti, Nermeen: "The Arrogance oOf Power", Al Ahram Weekly, Aug. 1723, 2006, at http://weekly.ahram.org.eg/2006/808/re701.htm.
} 
hostility it generates in the Muslim world. Israel's practices in the occupied territories-the rampant new construction of settler facilities, the frequently tolerated acts of settler violence against Palestinians' property and persons, and the wide array of legal restrictions impinging on Palestinians' daily life-have all mightily contributed to the widespread sense of grievance among Arabs of all religions in the Muslim World. ${ }^{40}$ On the whole, Europeans have long been acutely aware of this and have wisely moved to distance themselves from Israel, and particularly from that country's leading right-wing elements. In contrast, the United States, at least until now, has been slow to recognize the danger of too close an association with the Jewish state.

In early December, 2012, following the UN General Assembly's modification of Palestine's status and the Israelis' furious reaction, Peter Beinart published an article in Newsweek indicating that unnamed "senior officials within the administration" were predicting that the Obama team would adopt a new approach to the Palestine issue in its second term: "Benign Neglect." 41 According to one official, the new approach hinged on the notion that "the tide of global opinion is moving [against Israel]." This led the official to the conclude that "America's 'standing back' is actually 'doing something.'" The strategy's full logic is that the United States should now stand back and let the rest of the world do the confronting, for: once Israel feels the full brunt of its mounting international isolation, its leaders will be scared into changing course. ${ }^{42}$

"To some outside observers," notes Beinart, "it all sounds too clever by half." He goes on to point out that one critic, former U.S. ambassador to Egypt and Israel, Daniel Kurtzer, maintains that so long as Washington continues to "protect Israel from prosecution at the International Criminal Court, Netanyahu won't suffer enough internationally to reconsider his ways." ${ }^{43}$ Others charge the president is simply motivated by cowardice, and fears to confront Israel and its well organized supporters in the United States. ${ }^{44}$ If Obama's recent visit to Israel was a product of the administration's "Benign Neglect" approach, its limitations are glaringly evident.

\section{What Now? The Rest of the Obama Era}

Should Beinart's theory of Benign Neglect pan out, the rest of Obama's second term promises to be bleak for peacemaking efforts in Palestine. The president left himself very little "wiggle room" in his Jerusalem speech. Beinart's appraisal of the administration's new approach as being "too clever by half" may not only turn to have been correct, but also the most appropriate epitaph for the two-state solution. Benign Neglect seems, to say the least, very unlikely to sway Netanyahu into abandoning his determined effort to devour the West Bank.

Presuming that tensions with Iran remain more or less static, the remainder of Obama's tenure will therefore probably be marked by intermittent quarrels between Washington and Jerusalem over Israeli policy-makers' efforts to increase the numbers of Jewish settlements in

\footnotetext{
${ }^{40}$ See FMEP Reports; see also http://www.fmep.org/about.

${ }^{41}$ Beinart, Peter: "Why Obama Will Ignore Israel", Newsweek, Dec. 10, 2012, at http://www.thedailybeast.com/newsweek/2012/12/09/why-obama-will-ignore-israel.html.

${ }^{42}$ Ibid.

${ }^{43}$ Ibid.

${ }^{44}$ Ibid.
} 
the occupied Arab territories or to expand existing ones. The precedent set by Obama in his Jerusalem speech suggests a predictable pattern: the Obama Administration will express verbal disapproval, and perhaps even condemnation, of Israel's practical steps to strengthen its settlers' presence on the West Bank, but will take no effective action to influence the Jewish state's policies. In turn, this will probably lead to a prolongation of the current situation, including recurrent clashes between Israel and the Hamas regime in Gaza with the attendant danger of a spiral of violence spinning beyond the control of any actor. If Obama succeeds in kicking the ball down the road, he will bequeath the same problem to a successor, complicated by the additional time Israel will have gained to incorporate settlements into its national system.

On the other hand, it is not yet totally impossible for Obama to reverse his position and commit himself to rescuing the two-state solution. Although there is but a small chance of this-and one that will rapidly diminish as his second term unfolds-the president did manage to squeeze into the March 21 Jerusalem speech sufficient qualifications to reverse himself. In the unlikely event that this were to occur, history, as well as changes in American public opinion, may carry useful lessons for navigating the tricky currents of White HouseIsraeli relations.

In 1944, at a time when the acerbic American Zionist leader Abba Hillel Silver had come close to entering into a direct confrontation with President Franklin D. Roosevelt, the moderate Zionist leader Dr. Nahum Goldmann cautioned his colleagues on the American Zionist Emergency Council in these stark words:

Antagonizing the president of the United States is a serious matter.... If this fight....and this policy of attacking the Administration is continued it will lead us-and I choose my words very carefully— to complete political disaster. ${ }^{45}$

A key feature of the American political system is what Theodore Roosevelt once called the "bully pulpit," the office of the presidency's power to manufacture, and appeal to, public support for White House policy preferences. It was this powerful weapon that President Dwight D. Eisenhower employed to force a very reluctant Israeli Prime Minister, David Ben Gurion, to order the withdrawal of Israeli troops from Egypt's Sinai Peninsula following the 1956 Suez War. Failing to find congressional support for for his demand that Israel pull back from the occupied Egyptian territory, Eisenhower brought his case directly to the American people. His stand led to Israel's departure from the Sinai the following month. In a major television and radio speech to the American public on February 20, 1957, Eisenhower rhetorically asked and answered one major question:

Should a nation which attacks and occupies foreign territory in the face of United Nations disapproval be allowed to impose conditions on its own withdrawal? If we agreed that armed attack can properly achieve the purposes of the assailant, then I fear we will have turned back the clock of international order. ${ }^{46}$

\footnotetext{
45 Cited in Schechtman, Joseph B. (1966): The United States and the Jewish State Movement, New York, Herzl Press, p. 83; See also Tschirgi, Dan: "The Context of Israeli-Palestinian 'Final" Negotiations," UNISCI Discussion Papers, no. 26 (May, 2011), p. 18, at http://www.euromesco.net/index.php?option=com_content\&view=article \&id=1731\%3Athe-context-of-israelipalestinian-final-negotiations- \&catid=88\%3Amembers-publications\&Itemid=79\&lang=en.

46 "Eisenhower's Radio and Television Address to the American People on the Situation in the Middle East", Jewish Virtual Library, February 20, 1957, at http://www.jewishvirtuallibrary.org/jsource/History/ikewarn1.html.
} 
The bully pulpit was also the same weapon that years later-in 1977-another American president, Jimmy Carter, refused to use when he clashed with Israeli Defense Minister, Moshe Dayan, much to the distress of National Security Advisor Zbigniew Brzezinski. On that occasion, the issue involved plans for a general peace conference in Geneva. Brzezinski, along with Secretary of State Cyrus Vance and Israeli Ambassador Simcha Dinitz, was in the New York hotel room where the events unfolded. Brzezinski recalls the encounter in these words:

Dayan in effect blackmailed the President...at one instance, Dayan said, 'We need to have some agreed formula, but I can go to Israel and the American Jews. I have to say there is an agreement and not a confrontation.' To which the President replied, 'We might have a confrontation unless you are willing to cooperate. But a confrontation would be very damaging to Israel and to the support of the American public to Israel.'

....In the end, we got a compromise statement [Carter] was quite tough; but he didn't go far enough, in my judgment, to indicate that if challenged he would go to the country and there would be an all-out confrontation. ${ }^{47}$

Public opinion in the United States is now clearly no longer as reflexively pro-Israel as it was once. Alvin Richman, formerly an analyst of public opinion with the State Department and the US Information Agency, and now a private consultant, produced a paper in 2010 entitled "Attitude Factors in the Search for Israeli-Palestinian Peace: A Comprehensive Review of Recent Polls." ${ }^{48}$ Richman's careful analysis reinforces the case that Obama might have successfully confronted Israel's right wing government.

While a significant majority of Americans retain their long-established preference for Israel rather than Palestinians (63\% to 15\%), "most ...prefer that the U.S. not take sides in the Israeli-Palestinian conflict."49 When World Public Opinion. Org asked "which side the U.S. should take" in the Israeli-Palestinian conflict, "a majority of those replying said the U.S. should not take either side ( $71 \%$ ), compared to $21 \%$ who wanted the U.S. to take Israel's side and 3 percent take the Palestinians' side." ${ }^{50}$

Since 1994, Gallup Polls have "consistently shown that Americans predominantly favor the establishment of an independent Palestinian state on the West Bank and the Gaza strip."'51 This is in keeping with earlier studies of U.S. public opinion. Polls taken by the Program on International Policy Attitudes (PIPA) going back to 2001 found a solid majority of Americans (77\%) supporting the idea of a Palestinian state. ${ }^{52}$ Earlier polls further established two major additional aspects of public opinion in the United States. The first was the 2003 Gallup finding that Americans overwhelmingly (87\%) considered resolution of the Palestinian-Israeli conflict as an "important goal" for U.S. foreign policy. ${ }^{53}$ The second finding of polls taken in

47 Brzezinski, Zbigniew (1983): Power and Principle: Memoires of a National Security Adviser, New York, Farrar, Straus, Giroux, pp. 108-09.

${ }^{48}$ Richman, Alvin: "Attitude Factors in the Search for Israeli-Palestinian Peace: A Comprehensive Review of Recent Polls", World Public Opinion, September, 2010, at http://www.worldpublicopinion.org/pipa/articles/brmiddleeastnafricara/666.php.

49 Ibid., p. 10.

${ }^{50}$ Ibid.

${ }^{51}$ Ibid.

52 "Israel and the Palestinians, Support for a Palestinian State", Americans and the World Digest, at http://www.americans-world.org/digest/regional issues/israel/palestinians/pressure.cfm.

53 "Israel and the Palestinians, Importance of the Middle East to the US", Americans and the World Digest, at http://www.americans-world.org/digest/regional issues/IsraelPalestinians/pressure.cfm. 
2002 (PIPA as well as a poll conducted by the Christian Science Monitor and Investors Business Daily) related to the issue of Israeli settlements in the occupied territories. Both surveys found that "a modest majority" believed that Israel should not construct settlements in the West Bank and Gaza. ${ }^{54}$

In 2012, the broad outlines of US public opinion remained essentially similar. At the height of Israel's attack on the Hamas-controlled Gaza Strip in November, 57\% of Americans held that Israel was "justified" in taking military action against Hamas and the Palestinians in the area known as Gaza, while only $25 \%$ viewed Israel's policies as "unjustified." 55 Just before the end of 2012, one major analyst of public opinion in the United States reviewed several polls and concluded that:

While there are differences among Americans, most support the Israelis more than Palestinians. But a very clear majority also looks forward to a two-state solution. ${ }^{56}$

Politically, this is very much what was in the balance as the summer of 2013 appeared on the calendar.

Events in the Middle East moved quickly over the next several months. In mid-June, Iran's presidential elections produced a landslide victory for Hassan Rouhani-a prominent cleric who was well known to the West as a committed moderate. Rouhani soon showed a willingness to live up to his reputation, calling for renewed dialogue with the West aimed at "reducing enmities." 57 The White House immediately responded that Rouhani's presidency offered Iran "an opportunity to... act quickly to resolve the international community's deep concerns over Iran's nuclear program." 58

In early July, Egypt's military overthrew the legitimately elected Islamist-dominated government of Mohammed Morsi and established an interim military regime under the leadership of Morsi's Minister of Defense, General Abdel Fattah el-Sisi. Six weeks later, Egypt's new rulers unleashed a bloody offensive against die-hard Muslim Brotherhood supporters who insisted that Morsi be restored to the presidency. ${ }^{59}$

In the meantime, the pace of the summer's fast-moving events in the Middle East did not abate. On July 19, Secretary of State John Kerry announced that Israel and the Palestinian Authority had agreed "on a 'basis' for returning to peace talks on 'final status' issues." ${ }^{60}$ As of now, these talks_-replete with all their dramatic uncertainty—are still ongoing.

A week after the massacres in Cairo, some 1,500 Syrians were killed by a gas attack in the environs of Damascus. Although nobody denied the fact of the attack, the Syrian regime and the rebels blamed each for the atrocity. Convinced of the Asad regime's culpability, the

\footnotetext{
54 "Israel and the Palestinians, Attitudes Toward Israeli Settlements", Americans and the World Digest, at http://www.americans-world.org/digest/regional issues/IsraelPalestinians/pressure.cfm.

55 Enten, Harry J.: "Where is US Public Opinion on Israel, Palestine and the Gaza Conflict?", The Guardian, November 19, 2012, at http://www.guardian.co.uk/profile/harry-j-enten.

${ }^{56}$ Ibid.

57 Rezaian, Jason: "Ruhani Sworn In as Iran's President", The Washington Post, August 4, 2013, at http://articles.washingtonpost.com/2013-08-04/world/41067340_1_hassan-rouhani-iranian-president-iran-s. ${ }^{58}$ Ibid.

${ }^{59}$ The full death toll remains uncertain, although it seems very likely to have fallen between the government's figure of approximately 1000 and the claims of Muslim Brotherhood spokesmen, which ranged up to 4000.

${ }^{60}$ LaFranchi, Howard: “John Kerry: 'Basis' Reached for Renewed Mideast Talks; Initial Round in D. C.", The Christian Science Monitor, July 19, 2013, at http://www.csmonitor.com/USA/Foreign-Policy/2013/0719/JohnKerry-Basis-reached-for-renewed-Mideast-talks-initial-round-in-D.C.
} 
Obama administration found itself virtually required to act aggressively against the alleged violation of a so-called "Red Line" long since established by its own declarations. ${ }^{61}$ The upshot was that the President ordered Tomahawk-laden warships and submarines to positions offed the Syrian coast and informed the American people he was contemplating a limited military strike to ensure that Damascus would pay for having used a weapon of mass destruction against its own people. At this point Russian Foreign Minister Sergei Lavrov, responding to a clear diplomatic signal from Secretary of State Kerry, suggested a diplomatic resolution to the crisis: Syria—while not admitting guilt for the August 21 gas attack-would surrender its complete stock of chemical weapons to the international community which, in turn, would then destroy those same weapons. In return, the United States would not attack. The final act of this fascinating diplomatic ballet has not been reached yet.

Still, it remains clear that if an American president is going to rescue the two-state project from the headlong rush into expansionism that Israel's right-wing governments have promoted, Washington must very soon draw the line at countenancing further Israeli steps to undermine that solution. This, of course, will almost certainly require a major political confrontation between the U. S. and Israeli governments. President Obama should not have balked at the prospect earlier. So long as the United States retains its commitment to ensure Israel's security, he or any other president, would probably still be able to count on the support of most of the American people, including the bulk of American Jews, as well as that of the international community, and, quite possibly, a significant measure of support within Israel as well.

The real question is whether President Obama will have the required political courage to confront the issue effectively in a second term that may otherwise witness the full demise of the two-state option.

\footnotetext{
61“America, Syria and chemical weapons: Guttering, choking, drowning”, The Economist, August 27, 2013, at http://www.economist.com/blogs/democracyinamerica/2013/08/america-syria-and-chemical-weapons.
} 